Article

\title{
Best Practices for Fitness Center Business Sustainability: A Qualitative Vision
}

\author{
Jairo León-Quismondo ${ }^{1, *} \mathbb{C}$, Jorge García-Unanue ${ }^{2} \mathbb{C}$ and Pablo Burillo ${ }^{1}$ \\ 1 Faculty of Sport Sciences, Universidad Europea de Madrid, 28670 Madrid, Spain; \\ pablo.burillo@universidadeuropea.es \\ 2 IGOID Research Group, Department of Physical Activity and Sport Sciences, University of Castilla-La \\ Mancha, 45071 Toledo, Spain; jorge.garciaunanue@uclm.es \\ * Correspondence: jairo.leon@universidadeuropea.es; Tel.: +34-912-113-505
}

Received: 19 May 2020; Accepted: 18 June 2020; Published: 22 June 2020

\begin{abstract}
The growing interest in fitness services is demanding optimal service management and operation. This research aims to identify the best practices in fitness center management for increasing customer engagement and for long-term stability and sustainability of the business. A qualitative approach through 23 semi-structured interviews to fitness center managers was performed in Spain, covering private centers with diverse business models ( 7 low-cost, 13 mid-market, and 3 premium). The managers were asked about their characteristics, the fitness center characteristics, and the managerial decisions and individual opinion. The results showed the best practices divided into five sections: customer service, offered service, marketing, facilities, and general terms and conditions. Kind customer service, the existence of loyalty programs, enough tangible quality, and online marketing strategies are essential for fitness centers' success. Additionally, a fair fee and a maximum of a $15 \mathrm{~min}$ trip to the center should be guaranteed. This information has clear implications for promoting sporting habits and for engaging more people in physical activity, complementing the extensive quantitative data in the existing literature.
\end{abstract}

Keywords: fitness centers; sports management; business sustainability; qualitative; customer service; customer engagement; sports facilities

\section{Introduction}

The increasing level of participation in physical activity during the last decades has led to a growing number of sports centers. This progress translates into more than 210,000 fitness centers worldwide, serving over 183 million members [1], and 63,644 clubs in Europe with 64.8 memberships [2]. In this context, fitness centers have become the reference sports facilities, helping sport promotion among society and adherence to physical activity $[3,4]$. Consequently, the fitness market has acquired greater complexity. The emerging business models, such as boutique or low-cost centers, are some examples of the process of professionalization and diversification $[5,6]$.

Nevertheless, although general levels of physical activity participation have risen, a high prevalence of physical inactivity remains [7]. Almost half of the Europeans state that they never exercise, Spain being one of these countries, with high levels of inactivity (46\%) [8]. Therefore, adherence to physical activity programs requires substantial improvement. Fitness centers have the possibility of attracting new demand, positively impacting society. Particularly in Spain, the public-private collaboration through concessions has contributed to the democratization and expansion of the fitness culture, becoming more accessible for the different segments of customers. The Spanish fitness industry is the fourth European market in terms of revenue with a penetration rate of $11.7 \%$ of the total population [2]. 
In this situation, different centers try to engage new and existing customers, achieving a more advantageous position through the application of different strategies. Associated with this changing scenario, an updated service according to the trends in the fitness industry has become essential for attracting customers and, subsequently, for increasing the penetration rate in the society. In this line, the scientific production on fitness trends is of great concern, both worldwide [9] and in Europe [10], with progressively more presence of technology. As the professionalization and rivalry between centers increase, the need for adding value to services becomes essential.

The current interest of the population in fitness center services and its complexity makes it necessary to improve their managerial practices. Successful business management of fitness centers is responsible for the wellbeing of the company and, consequently, for the wellbeing of the customers that engage in physical activity. Organizations that fail to sustain their position in the fitness market increase their chances of disappearing or adapting to new markets. Long-term sustainability of the business is required in the current rapidly changing world, meaning that fitness centers will be viable and stable for many years to come.

Fitness and sports center services have a rich body of accumulated knowledge. However, the scientific traditional approach has been through quantitative data sources. In such a complex market, qualitative design with a holistic approach is extremely useful to conceptualize at an operative level the managerial strategies to follow. Through a global and comprehensive approach, it is possible to effectively manage risks associated with the uncertainty of the fitness industry.

In order to supplement the extensive quantitative data of previous work and to achieve a deeper understanding of fitness centers' best practices that contribute to ensuring the long-term sustainability of the business, this research aimed to identify the best practices in fitness centers for increasing customer engagement and for the long-term stability and sustainability of the business. In view of the aforementioned apparent gap in the literature, the following research question is addressed: Are there certain managerial decisions that determine the stability and success of fitness centers?

\section{Literature Review}

\subsection{Customers of Fitness Centers}

The offer of sports services is rising concurrently with the increasing number of individuals demanding physical activity-related services. Customers can now access a wide offer of services and they are familiar with similar ones [11]. This level of knowledge has increased their expertise, making their expectations and perceptions even more complex [12]. In this regard, specific segments of fitness customers have previously been identified according to their exercise motives [13] and sociodemographic characteristics [14]. Additionally, differences in service perception according to gender and age have been established in previous research [15].

The profile of the customer of sports services has been widely addressed. Effects of customer satisfaction [16-18], service quality [19-21], perceived quality [6,22-24], and loyalty [6,25,26] have been of high concern. These contributions have led to the creation of prediction models that forecast the probability of customer dropout $[4,27,28]$. The previously referred factors affect business stability, not only in terms of members' continuity but also the long-term business sustainability in terms of profitability and financial indicators [29].

\subsection{Managers of Fitness Centers}

The growing specialization in the fitness industry is also noticeable in management positions. Fitness center managers face problems that require progressively more complex solutions. In this process, accurate decision making is crucial [30]. Despite the different points of view and functions regarding the managers of fitness centers, the most common perspective considers it as the person in charge to lead the organization of the sports services for its success [31]. 
The effective operation and attractiveness of sports organizations are possible thanks to the correct decisions of managers while conducting the organization. They should proceed professionally in such a competitive environment $[32,33]$. As a consequence of progressive professionalization, specific sport managers' competencies [33-35] and functions [36] have been studied.

As previously stated, the scientific production on managers of fitness centers is less abundant than research on the customer's profile. Previous research has focused on either the role of the manager of sports services [37] or the profile of managers [38,39]. However, a need to hasten a still scarce scientific production [40] is required to bridge the remaining theory-practice gap [41,42].

\subsection{Best Practices in Fitness Centers}

Despite the big efforts made in the study of the fitness industry and its effect on a healthy and active lifestyle, the great speed of change urges to offer updated data regarding managerial decisions. The identification of the best practices in fitness centers is essential for improving the academic knowledge of the sector and for applying accurate managerial decisions. Thus, the development of adequate protocols and reliable procedures in fitness centers would help to increase the engagement of customers in fitness services, leading to more stable and sustainable businesses. Two of the most difficult tasks identified in the long-term management of sports organizations are dealing with people and having sufficient financial provision. In this context, the building of a stable and sustainable core of the organization, through appropriate cooperation with the stakeholders, has a significant impact on its success [43].

In business, the best practices try to provide clear guidance to professionals. Their origin is a combination of both research and experience. In the fitness market, there is no record of recent research on the best managerial practices. However, the study of fitness centers has allowed to know a number of key factors that lead to sustainable fitness centers [44]. Some research suggests that sports programs, personnel, and the physical environment are the most important attributes for fitness center management [23]. Additionally, more recent studies exhibit the core and complementary services, the facilities, and the employee competencies as the main elements [45].

\subsection{Qualitative Research in Sport}

As evidenced, the traditional approach to the existent problem in the sports and fitness industry has been performed through quantitative research. However, the closed nature of quantitative questions could be enriched with qualitative data. A qualitative method allows focusing on sports services from a holistic perspective. Through a qualitative research process, a greater understanding of the reality of fitness centers is achieved as they are in natural situations [46].

Despite some qualitative studies starting to add cumulative knowledge to the existing literature, a clear gap remains. Nevertheless, there are some interesting applications of qualitative research in the sports and fitness management scope. Some examples are qualitative research on artificial turf football fields, allowing to identify the most important parameters for the design and safety, from the perspective of professional footballers and coaches [47]. Additionally, the influence of different factors on customer dropouts in fitness and wellness centers has also been addressed through qualitative semi-structured interviews [48].

Thus, the present research tries to supplement previous quantitative work in the area of fitness services. A qualitative method may shed light on the understanding of the complex and multifactorial reality of fitness centers. Thanks to this method, a deeper knowledge of the phenomenon is acquired, through the collection of opinions, beliefs, experiences, and reflections of key informants. In the following sections, the materials and methods are presented, addressing the sample of 23 key informants (fitness center managers), the design of the semi-structured interview, and the procedure. The results and discussion are presented following previous qualitative research $[47,48]$. 


\section{Materials and Methods}

\subsection{Participants}

The sample was composed of 23 managers of fitness centers, aged between 22 and 50 years old $(\mathrm{M}=33.91$; $\mathrm{SD}=9.26)$, with an average experience in similar positions of 6.34 years $(\mathrm{SD}=5.32)$. The participation requirements were to conduct privately managed fitness centers located in the Community of Madrid, Spain, not oriented to a simple sport modality or martial arts, with at least one weight room with machines and free weight, and one or more rooms for group classes. Different business models were considered, including low-cost centers ( $n=7$ managers), mid-market centers ( $n=13$ managers), and premium centers ( $n=3$ managers).

The sample size was considered appropriate. As demanded in qualitative studies, the saturation point was reached with 23 key agents, meaning that an increase in the number of interviews would not provide new information or themes $[47,49]$.

\subsection{Instrument}

Qualitative research with a cross-sectional method was performed through semi-structured interviews.

The first step consisted of a literature review [16,50-54] and a first draft of the interview, involving 18 items regarding personal characteristics, the fitness center characteristics, and the fitness center management. As the second step, the instrument was reviewed by a panel of experts composed of four $\mathrm{PhD}$ university professors with a research experience of more than five years, and two fitness center managers with more than five years of experience in similar positions. Afterward, specific questions were refined and added.

Finally, a pilot test was conducted on 4 fitness center managers, proving the consistency of the interview. The final instrument consisted of 20 items divided into three sections about the manager characteristics, fitness center characteristics, and managerial decisions and individual opinion.

\subsection{Procedure}

The participants were contacted personally and invited to voluntarily collaborate in the study. In some cases, the interview was completed at that moment, whereas in other cases, a posterior meeting was appointed. All the participants accepted to be voice-recorded for research proposes, always ensuring the anonymity of their responses. The average duration of the interviews was $17.41 \mathrm{~min}$ $(\mathrm{SD}=6.82)$. All of them were conducted by the same researcher.

\subsection{Data Analysis}

The data analysis was performed following previous research $[47,48]$. The interviews were completed and literally transcribed simultaneously, as required by the Constant Comparative Method [55]. Afterward, ATLAS.ti v.7.5.4 for Windows was used to organize the gathered information. As recommended by previous work [56], an inductive approach was followed. The codes emerged from the interviews and they were later classified into families (Table 1).

Finally, for a better understanding, the information is presented as diagrams, following the recommendations in previous qualitative studies $[47,48]$. 
Table 1. List of codes, grounded and relation with families.

\begin{tabular}{ccc}
\hline Codes & Grounded & Families \\
\hline Human resources & 129 & \\
Instructors & 23 & Customer service \\
Loyalty & 18 & \\
Reception & 11 & \\
Personal treat & 7 & \\
Familiar treat & 5 & \\
Complaints & 4 & \\
Group classes & 46 & \\
Service quality & 20 & \\
Technology & 5 & Marketing \\
Supplementary services & 2 & \\
\hline Traditional tools & 17 & \\
Business competition & 15 & \\
Recommendation & 22 & \\
Brand image & 12 & \\
Special offers & 7 & \\
Social networks & 6 & \\
Customer acquisition & 6 & \\
\hline Locker rooms & 38 & \\
Level of maintenance & 21 & \\
Cleanliness & 19 & \\
Large spaces & 15 & \\
Equipment & 15 & \\
Importance & 13 & \\
\hline Price & 29 & \\
Location & 21 & \\
Opening days & 6 & \\
Opening hours & & \\
On-site parking & & \\
\hline
\end{tabular}

\section{Results}

The results are presented through diagrams. Additionally, detailed information and extracts from the interviews are provided. The findings are revealed organized into five sections:

- Customer service: the set of strategies developed by fitness centers through their employees to optimize the interaction with users.

- Offered service: including the core services, basic sports services that are fundamental for the business, and supplementary services, not essential, but adding value to the core service.

- Marketing: regarding the strategies and tools used by fitness centers for acquiring or retaining customers.

- Facilities: the physical environment where the activity of the fitness centers is developed, whether intended for sports activities or not.

- General terms and conditions: requirements or clauses accepted by the customer during his membership.

\subsection{Customer Service}

The most important results regarding customer service are highlighted in Figure 1. Following recommendations of the inductive method, as the interviews were being conducted, specific themes emerged. Following the previous research, each emergent theme was coded and, later, classified into a family. 


\begin{tabular}{|c|c|c|}
\hline FAMILY & CODE & EMERGENT THEME \\
\hline \multirow{7}{*}{$\begin{array}{l}\text { CUSTOMER } \\
\text { SERVICE }\end{array}$} & Instructors & $\begin{array}{l}\cdot \text { Willingness to help } \\
\text { - Number of instructors }\end{array}$ \\
\hline & Reception & $\begin{array}{l}\cdot \text { Wait time } \\
\cdot \text { Confidence } \\
\cdot \text { Specialized in their position }\end{array}$ \\
\hline & Personal treat & - Emotional link \\
\hline & Familiar treat & $\begin{array}{l}\text { - Mid-market centers } \\
\text { - Proximity-based centers }\end{array}$ \\
\hline & Complaints & $\begin{array}{l}\text { - Resolutive } \\
\text { - Strategies according to size of center }\end{array}$ \\
\hline & Loyalty & $\begin{array}{l}\text { - Customer rotation } \\
\text { - Loyalty plans }\end{array}$ \\
\hline & Human resources & $\begin{array}{l}\cdot \text { Employee satisfaction } \\
\cdot \text { Requirements/preferences } \\
\cdot \text { Training }\end{array}$ \\
\hline
\end{tabular}

Figure 1. Customer service: relations between families, codes, and emergent themes.

Customer service plays a determining role from the perspective of the interviewed managers since it is claimed to be the factor that worries them the most. This concern is present, independently of the business model, including low-cost, mid-market, and premium centers.

"In my view, the customer service is the most important point of the service in a sports center" (Manager 16).

Firstly, instructors are considered fundamental pillars of customer service. They should show a willingness to help the users, making them feel they are receiving appropriate assistance. Subsequently, the number of available instructors should be enough, giving members the possibility to address them.

"For example, the fitness room should be dynamic, always with instructors in the room, avoiding customers to be looking for an instructor to keep training" (Manager 1).

Secondly, the reception area is also considered highly important since the customer service encompasses from the moment the user enters through the door until they leave the facility. During this process, they believe that attention should be based on trust and confidence, avoiding waiting time, and offering solutions. Some less frequent opinions emphasize that reception tasks should be performed by specialized employees, avoiding receptionist-instructor figures.

"In reception, friendly people who are well informed of all the activities of the center, providing accurate information and avoiding leaflets with the fees when someone asks for information" (Manager 18).

Two basic requirements for success regarding the customer service are a combination of a personal treat, thus generating emotional links, and a familiar type of treat, specifically in proximity-based centers with a mid-market orientation.

"After all, the user should feel like in a five-star hotel" (Manager 1).

The existence of complaints was a general concern among managers. Employees should offer solutions whenever possible and show a willingness to solve problems. Their strategies depend, to a large extent, on the size of the company and the number of members. Smaller centers follow strategies based on reliability and transparency through questions to their users. Larger centers apply protocols for incident detection. 
"If there is a problem, users tell us in confidence [ ... ]. There are never big problems because it ends up being like a family" (Manager 19).

Managers considered it necessary to implement loyalty programs, rewarding senior members, and making the decision of unsubscribing more difficult. Exact results are not provided, but so far, the customer retention has had satisfactory improvement.

Some managers assured that employees should feel happy and motivated. By fulfilling these two premises, the employee's involvement will be greater and will positively affect the operation of the gym. Some managers felt concerned about keeping the same human resources for a long time, thus building a positive atmosphere in the fitness center. As they said, when a monitor leaves, customers perceive it. Regarding new instructors, they are required to hold appropriate certifications. Managers preferred new instructors to be multivalent and to have enough training in group classes. However, previous experience is not compulsory. Instead, when a lack of training is identified, managers lean toward group courses in the gym itself.

"Human resources play a key role. Imagine a completely empty gym, without a single machine. Having two people who know how to train, they can do you wonders" (Manager 5).

\subsection{Offered Service}

The second section addresses the offered service. Specific themes were revealed from the interview's analysis and the emerging codes (Figure 2). Themes regarding the group classes were the most common, followed by service quality. The supplementary services were much less common.

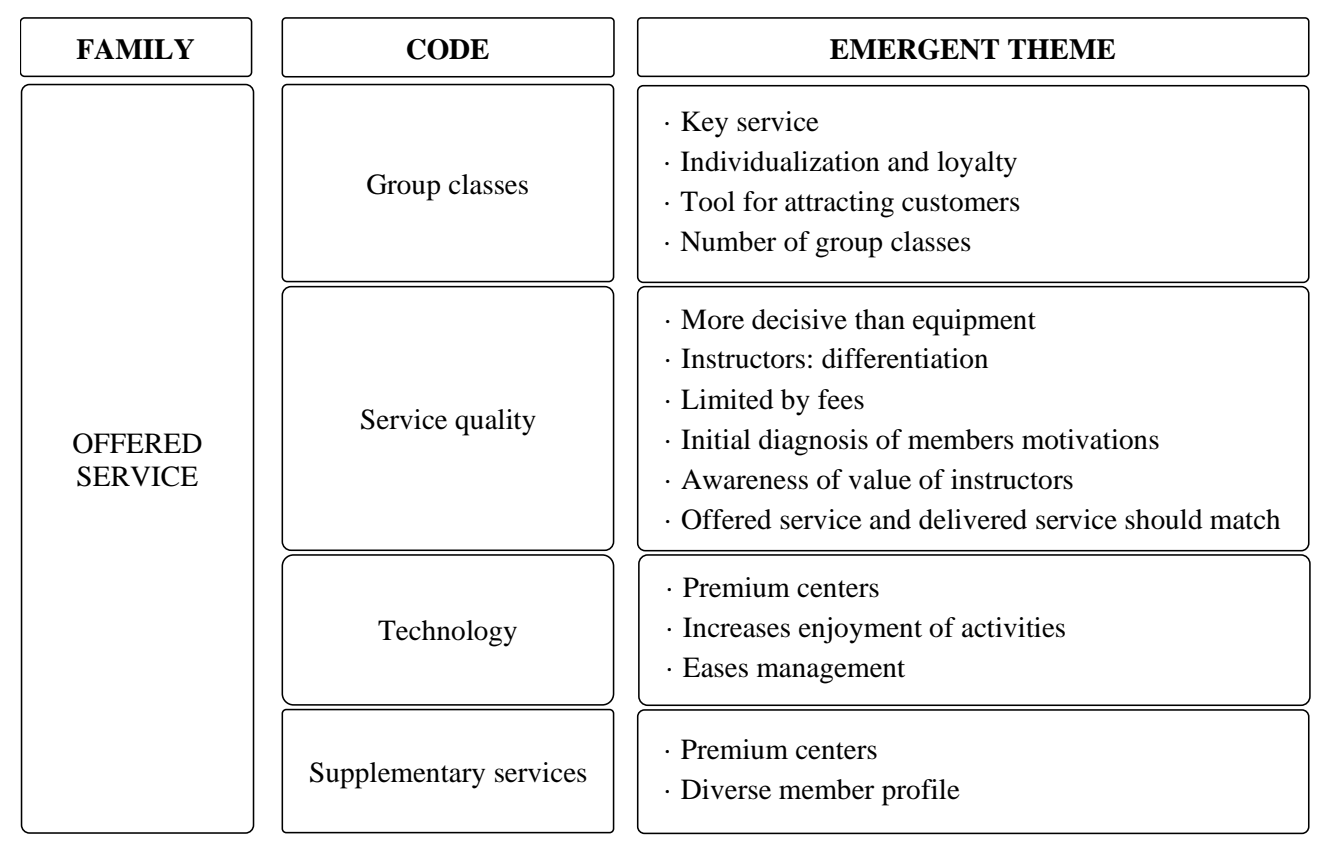

Figure 2. Offered service: relations between families, codes, and emergent themes.

The most important services for managers were, unquestionably, group classes. Many interviewees stated that their center operates properly thanks to them. Removing group classes would decisively affect the long-term sustainability and the economic balance of the fitness centers. Some reasons are the capacity of motivation, satisfaction, loyalty, and the possibility of working with a group with one single instructor. The number of group classes can also be used as a tool for attracting new customers.

"Maybe nobody is attending at six in the morning [ ... ]. In economic terms, you can think 'I am losing money,' but on the other hand, it is a marketing tool" (Manager 2).

Regarding the service quality, it is considered more important than the equipment. Some managers expressed that service quality is not given by the machines but by the staff. Thus, the work by instructors 
is considered as a differentiation factor. The informants believed that the service quality could be better with higher fees, but they understood the price is a decisive factor for users.

"Since this center works under public-private collaboration, the quality cannot be offered by machines but through the staff. This is our differentiation strategy, so clear" (Manager 16).

The best practices to increase the customer's perception of the quality of service also emerged. Initially, a full diagnosis of the customer's goals and motivations should be completed. As the member continues, they should realize the achievement of outcomes is thanks to the instructors' professionality. Lastly, during this whole process, a match between the promised service and the delivered service must be guaranteed.

"The initial assessment and where they want to be in the short, medium, and long-term. That initial contact is essential for a center like this" (Manager 7).

The presence of technology is not completely established in fitness centers but is emerging in premium centers. Technology adds value to centers with higher fees in two directions. Firstly, by increasing the enjoyment of practicing physical activity through technology in the fitness machines and, secondly, by making easier the management of new registrations and reservation of places in group classes. Supplementary services are also to be considered in centers with expensive fees, responding to a heterogeneous profile of customers and higher demands.

\subsection{Marketing}

Figure 3 exhibits the main ideas and tools regarding marketing strategies. The business competition forces to improve marketing actions. Different opinions about all of them were recorded.

\begin{tabular}{|c|c|c|}
\hline FAMILY & CODE & EMERGENT THEME \\
\hline \multirow{7}{*}{ MARKETING } & Business competition & $\begin{array}{l}\cdot \text { Main concern } \\
\cdot \text { Adaptation }\end{array}$ \\
\hline & Recommendation & $\begin{array}{l}\cdot \text { Inexpensive } \\
\text { - Customer experience }\end{array}$ \\
\hline & Brand image & $\begin{array}{l}\text { First impression lasts over time } \\
\text { Events: increase brand notoriety }\end{array}$ \\
\hline & Special offers & $\begin{array}{l}\text { - Simple and immediate } \\
\text { - Price-oriented }\end{array}$ \\
\hline & Social networks & - Essential for centers \\
\hline & Customer acquisition & $\begin{array}{l}\text { - Latent demand } \\
\text { Potential customer }\end{array}$ \\
\hline & Traditional tools & Newsletters, mailing, flyers, posters \\
\hline
\end{tabular}

Figure 3. Marketing: relations between families, codes, and emergent themes.

There is no consensus concerning the importance of marketing in fitness centers, but in general terms, managers did not consider marketing as a priority area for the success of their centers. However, they considered that the context of a high level of competitiveness makes imperative the adaptation of business to current times demands.

"Marketing has not been given much importance so far until now that so many gyms have come out" (Manager 11).

Opinions are presented from most to least important, from the managers' perspective. Firstly, the recommendation was considered the most powerful strategy. In addition, this method is inexpensive 
and suitable for every business model. A positive customer experience boosts the recommendation from current customers.

"We don't need advertising. Our members advertise us" (Manager 15).

Secondly, an improvement in the brand image leads to a more successful first impression. Following the managers, hosting events near the facility is an example that increases brand visibility.

"They see our center and, since it is [name of their brand], it conveys more confidence" (Manager 3).

Thirdly, providing special offers is a fast and easy strategy for targeting the most concerning factor for users, the price.

"We phone former members, customers who have dropped out" (Manager 14).

Fourthly, social networks are highly influential. Managers stated that they are aware of the great use of social networks today. They are based on immediacy and anonymity, allowing anonymous comments from customers.

"People feel braver in social networks. It seems they break free, free themselves, and they say much more" (Manager 16).

Participants considered that marketing strategies should also be oriented to non-active customers, allowing to reach more people than actual members, such as people who do not practice sport at present.

Lastly, some traditional marketing tools were identified from the opinions of managers. Newsletters, mailing, flyers, or street-poster advertising have traditionally been successful tools, but managers were aware of the limitations of these methods and did not consider them as key factors in their marketing strategies.

“No matter how many flyers you distribute, they will sign up for you for a month, but then they leave. Taking care of current customers is key" (Manager 2).

Very few managers referred to the website as an important element in their marketing, although most of the centers do have a web page.

\subsection{Facilities}

The most relevant results regarding the physical environment are shown in Figure 4, with locker rooms and the cleanliness as main concerns.

Fitness center managers considered that the physical environment in their services also has a high influence on their customers' satisfaction.

Although interviewees reflected the group classes to be the most important service in their centers, when we focus on the physical and tangible aspects, the weight room is the most used space of gyms. Finally, all the members go through it, regardless of whether they go to group classes or not. In addition, when asked about the pool, most of them agreed that it is an added value that acts just as a differentiation factor.

"After all, the swimming pool is the least used space in the center" (Manager 17).

Locker rooms are other spaces visited by every single member with high demand. The general agreement denoted that locker rooms should be clean. There were specific concerns on the safety and spaciousness of lockers, as well as the cleanliness and temperature in showers.

"It is the most important, after the weight room. What happens is we do not earn money from that, but it is extremely important. Lockers are the bottleneck through which $90 \%$ of people pass" (Manager 6).

As previously highlighted, from the point of view of all the interviewees, the factor where no mistakes are allowed is cleanliness. This is a key factor, not only in the locker rooms but also in activity spaces and passage areas.

"For me, it is very important the hygiene of the center. It is key. No mistakes are allowed here" (Manager 19). 


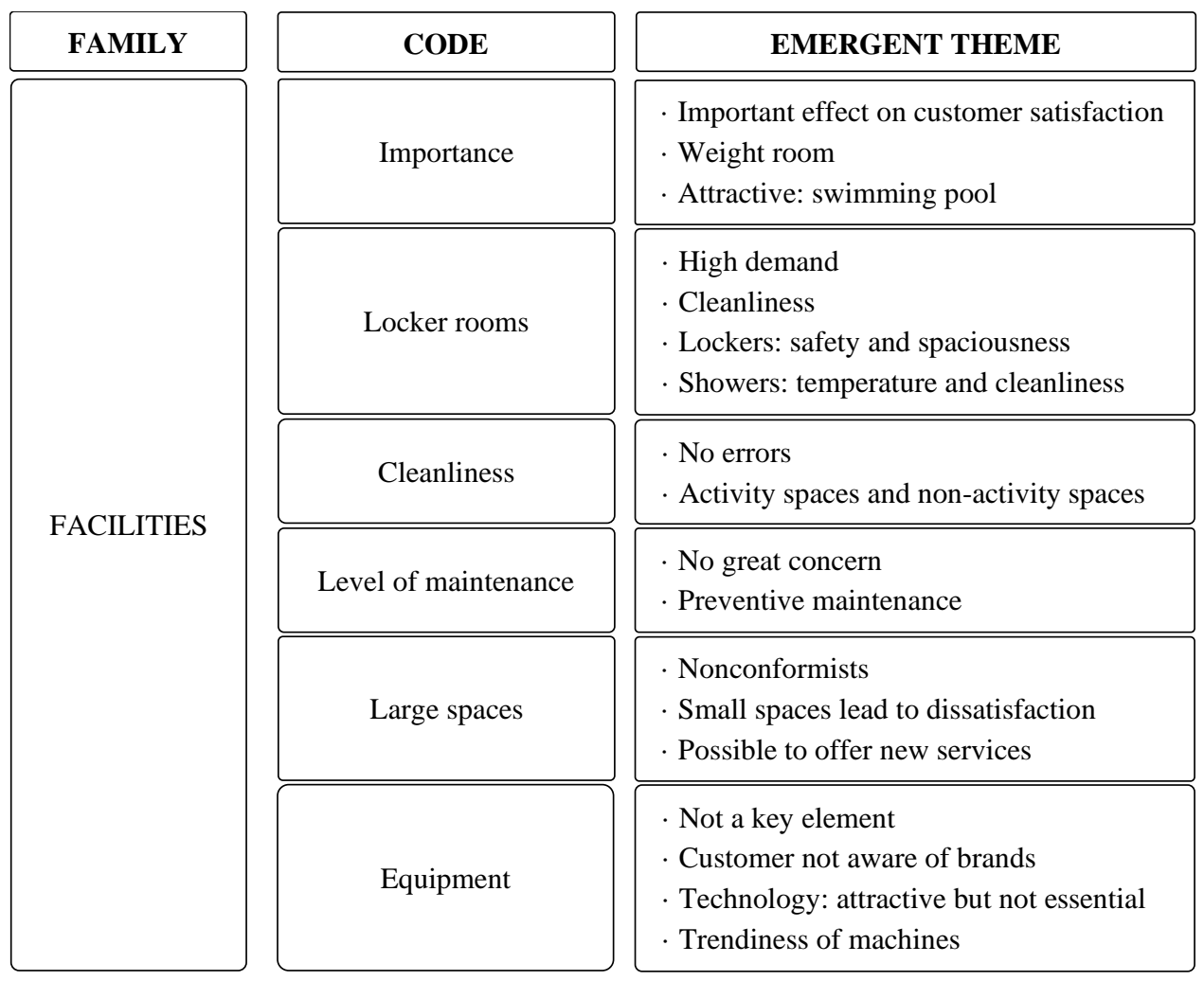

Figure 4. Facilities: relations between families, codes, and emergent themes.

A good level of maintenance of the fitness center was considered as a must for managers. However, they did not show great concerns since they considered that appropriate actions to contribute to the good maintenance of their center are being taken. For them, it was important to periodically renew the equipment, including machines.

"I think it is very important to let the customer know you are doing something every year" (Manager 3).

Managers felt dissatisfied with the current dimensions of their spaces. They believed that their service could improve with larger spaces, including new activities. The collected opinions suggested that larger spaces do not necessarily lead to satisfaction, but small rooms could lead to dissatisfaction.

"Having enough room to move, no congestion, not feeling crowded, and being able to move and exercise without elbowing others" (Manager 19).

Regarding the brand of the equipment, from the point of view of managers, it is not a key element for users. They believed that machines from recognized brands have a good presence, but most of the customers do not know the brand. They emphasized that technology, although not fundamental, is attractive to users, and particularly useful in premium centers. Additionally, managers of mid-market gyms warned that the great development in fitness machines benefits low-cost centers since they make it easier to exercise, even without instructors.

"Like in the industrial revolution: we are adding machines and firing people" (Manager 3).

\subsection{General Terms and Conditions}

The last section shows the general terms and conditions of the fitness centers, including fees, location, opening hours and days, as well as on-site parking (Figure 5). In the emergent themes, the most common beliefs can be observed, highlighting the importance of location. 


\begin{tabular}{|c|c|c|}
\hline FAMILY & CODE & EMERGENT THEME \\
\hline \multirow{5}{*}{$\begin{array}{l}\text { GENERAL } \\
\text { TERMS AND } \\
\text { CONDITIONS }\end{array}$} & Fee & $\begin{array}{l}\text { Decisive element } \\
\text { - Low-cost: strength } \\
\text { - Mid-market: fee according to service } \\
\text { Premium: customer profile }\end{array}$ \\
\hline & Location & $\begin{array}{l}\text { - Decisive element } \\
\text { · Maximum of } 15 \text {-minutes trip }\end{array}$ \\
\hline & Opening hours & $\begin{array}{l}\text { - Standard hours: } 7 \text { a.m. to } 11 \text { p.m. } \\
\text { - Adaptation }\end{array}$ \\
\hline & Opening days & $\begin{array}{l}\cdot 363 \text { days/year } \\
\text { - Closed: Christmas and New Year }\end{array}$ \\
\hline & On-site parking & $\begin{array}{l}\text { - Depends on each center } \\
\text { - Location and public transport connectivity }\end{array}$ \\
\hline
\end{tabular}

Figure 5. General terms and conditions: relations between families, codes, and emergent themes.

For the managers, the monthly fee was the main decisive element for choosing a gym. Low-cost fitness center managers considered the price as their main strength.

"Users consider the price over service quality. It is not a saying, it is just like that" (Manager 5).

In mid-market centers, the price should match the delivered service.

"Keeping fair fees for the services they receive, not excessive but not very low. Otherwise, customers, in my view, stop valuing properly their center" (Manager 10).

In premium centers, managers were aware of the target customer profile. Thus, fees should provide exclusivity and confidence to members.

"We are targeting a very specific profile. This is a premium center and we try to make the prices match the customer profile we have" (Manager 23).

From the managers' perspective, the center location is a success factor that determines the customers' decision when choosing a gym. There is consensus, considering fitness centers as proximity-based businesses, whose members are not willing to travel more than $15 \mathrm{~min}$ to the gym.

"People do not travel $15 \mathrm{~km}$ to go to the gym. This is a proximity-based business" (Manager 17).

When asked about the opening hours, they stated that fitness centers should have wide opening hours, generally ranging from 7 a.m. to 11 p.m. Gyms are being forced to adapt to this schedule for equal competition opportunities. However, the opening hours cannot be considered as a key factor since some managers believed that users end up adapting to the center's times. Furthermore, fitness centers usually operate 363 days a year, closing only on Christmas and the New Year.

"People adapt to your opening hours. It is important, but people adapt. It is a matter of adapting to people. If you offer the widest schedule in the world, users will continue wanting all the time in the world. However, if you offer certain hours, people end up adapting and training in these hours" (Manager 5).

Finally, the opinion of managers on the existence of on-site parking was divided. This element depends on individual factors of each sports facility, such as accessibility by public transport or location in the neighborhood.

Figure 6 shows the semantic mapping, relating the emergent codes and families. 


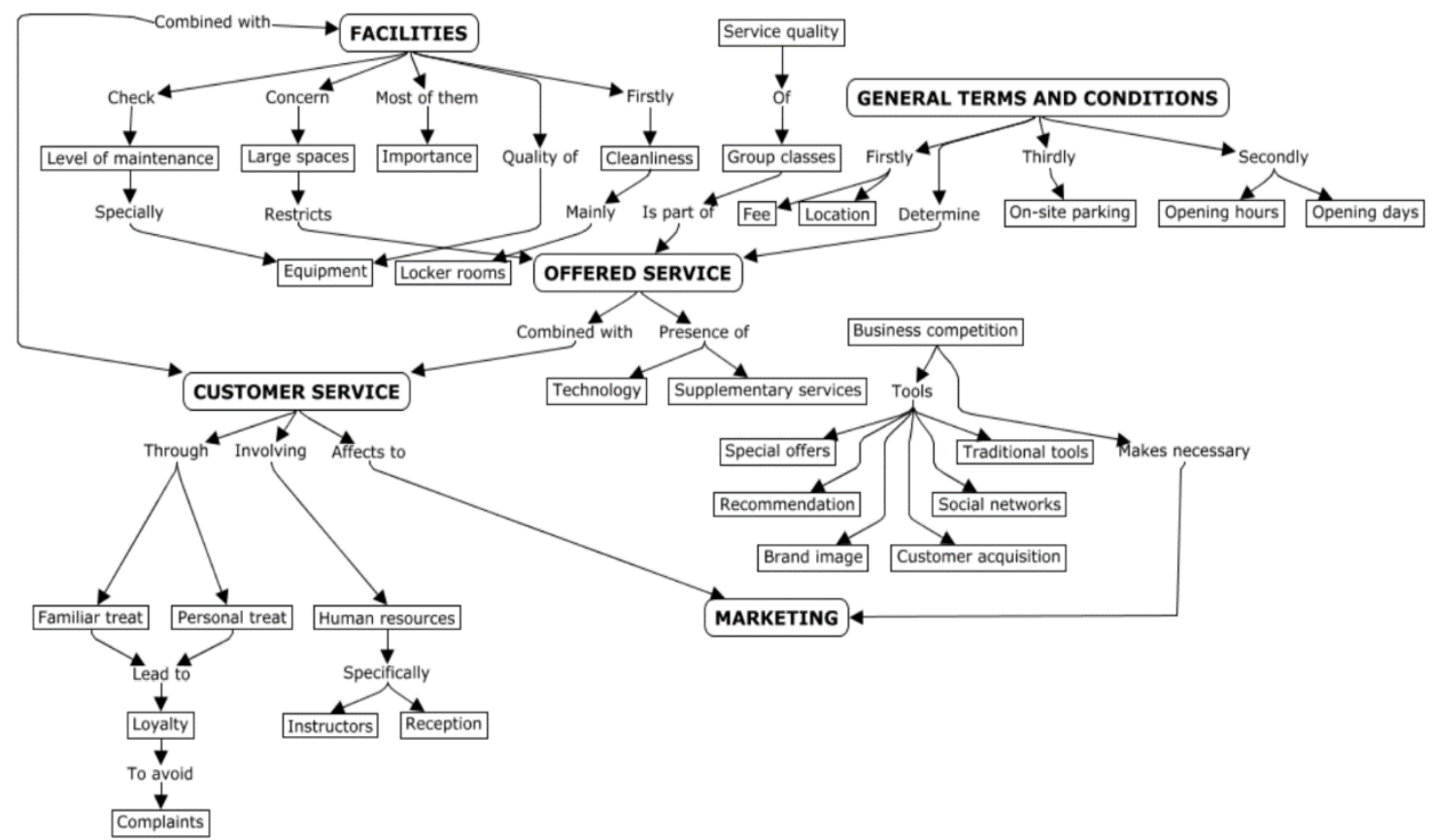

Figure 6. Semantic mapping.

\section{Discussion}

The identification of the best practices in fitness centers services is valued information for long-term sustainability. The high level of competitiveness and level of professionalism in the fitness industry makes imperative to have truthful information to make better decisions. This paper aimed to reach a deeper understanding of fitness center management and the best managerial practices for success.

The findings showed that customer service is an issue that concerns managers. As they develop their professional activity on the provision of services, and not product delivery, they understand that the interaction between employees and users is essential for all business models (low-cost, mid-market, and premium), above the tangible elements and physical environment. Despite the instructors interacting frequently with customers, the staff in reception also plays an essential role. These results show consistency with previous work, where human interaction emerged as the most relevant in health and fitness service-quality evaluation [57].

Even with appropriate customer service, complaints can arise. According to the managers, different sizes of centers lead to diverse strategies. On one side, the strategies in small centers are based on personal contact with users through direct questions. This usually happens in proximity-based centers with a mid-market orientation. The reliability and transparency allow employees to know the instant perceptions of customers about the service. However, in previous research, this feedback is perceived as scarce or non-existent by the customers [48]. On the other side, most of the low-cost centers are usually large in size. Their strategy is based on standardized procedures. Previous specific research denotes that large low-cost fitness chains manage suggestions, complaints, customer relations, and all payments by employing online platforms [6]. Regardless of the strategy, Rodríguez-Cañamero et al. [48] underline the importance of letting the customers know the complaints and suggestions process. Additionally, the existence of loyalty programs, through rewards or similar strategies, has been proved to be an efficient method for improving the long-term permanence of customers [58]. An efficient customer retention method is beneficial in operative and financial terms [25].

Another important area is the offered service in fitness centers. A general agreement establishes group classes as a best practice for sports centers. According to recent literature, group classes are the third worldwide trend in the fitness industry [9]. However, in Europe, traditional group classes are losing importance, in favor of small-group personal training [10]. In addition, previous research 
finds a positive relationship between group classes and the service experience, satisfaction, and future intentions [5]. No differences were established according to gender or age in our findings, despite the evidence in the literature about a higher preference of female members for group classes $[5,59]$. In this regard, the managers' responses warn that the presence of technology will gradually become a regular element in fitness centers and, specifically, in group classes.

Regarding the marketing, an offline strategy prevalence was observed, but an inclination towards online marketing, including social networks as the main tool. The two main social networks managers should use are Facebook and Twitter, helping to improve the brand image and providing information [60]. In addition, our findings are coherent with existing literature, showing that social networks should include opportunities for users' interaction with the center [61]. The brand image improvement is also something that concerns managers, in search of increasing customer recommendation. When acquiring products or services, customers proceed to recognize the brand and to associate the information about it. Thus, for authors like Chao [62], the brand image is a key factor for a positive relationship between companies and customers and would help to distinguish similar services offered by different companies.

The tangibles of fitness centers have also great implications for managers. The physical environment of the weight room and locker rooms is considered essential, although not as important as the customer service. This finding is coherent with previous studies, acting as customer satisfaction predictors [63]. The interviews provided detailed data, accepting the cleanliness as the most influential tangible element. Considering previous research, the importance of clean environments, specifically in locker rooms, is evident [44,48,64-66].

Regarding the size of sport spaces, a desire for larger rooms among managers was noticeable. However, this finding could partially contrast with Liu et al.'s [64] research on English public sports facilities, where small facilities outperform others.

Non-decisive areas in fitness centers were also identified, such as the swimming pool. This is not considered an essential area in fitness centers, since the profile of customer usually seeks more specific facilities. This finding also shows consistency with previous quantitative literature [15].

The monthly fee combined with the location of the center is critical for fitness centers' success, with a maximum of a $15 \mathrm{~min}$ trip and a fee according to the received service. Additionally to the location [67], the price was also identified as one of the main reasons for joining a fitness center, acting as an antecedent of the purchase decision [68].

Finally, it is worth mentioning the current state of the fitness industry. The COVID-19 pandemic has generated a radical change in sports services. However, this event has some associated opportunities that do not necessarily confront our findings. The presence of technology and digitization generates an opportunity in the management of sports facilities, easing managing processes. Despite the social distance, customer service must continue being warm. Regarding the cleanliness and the necessary disinfection protocols, they will continue being necessary for the post-COVID-19 era.

\section{Conclusions}

This research provides useful information for avoiding customer dropout, improving member acquisition, and better service provision in fitness centers through the implementation of the best practices. Specific managerial decisions were proved to be determinant for fitness centers' success and for long-term sustainability. Firstly, kind customer service from both reception and instructors is demanded. For that purpose, loyalty programs should be extended, increasing customer satisfaction and raising retention. Secondly, the intangible side of the service is essential but should be completed with good tangible quality, which translates mostly in clean and hygienic activity spaces and locker rooms. Thirdly, the quality and trendiness of group classes highly influence the perception of the offered service, where technology is increasingly adding value to the activities. Regarding marketing, more online strategies should be applied through social networks. Finally, a fair combination of 
monthly membership, according to the received service, and location, with a maximum of a 15-min trip, should be guaranteed.

This research tried to bridge the existent theory-practice gap. On one side, there are profound managerial implications for the people in charge of fitness services. Fitness centers should consider these findings for better operation in their daily activities. Managers need to articulate a series of strategies for increasing customer engagement as a guarantee of business stability. On the other side, it has scientific implications, since this work supplements previous quantitative data, giving the full picture of the industry.

However, this work deals with some limitations. Firstly, the availability of time of the key informants was occasionally limited. Their lack of time caused some of the interviews to be shorter than desirable. Although all the foreseen topics were addressed in all of the interviews, the ideal length would have been occasionally longer. Another limiting factor was the inclusion criteria, which was focused on managers of private fitness centers. Therefore, when extrapolating the conclusions to public organizations, the conclusions may be limited to the characteristics of the sample characteristics.

Future lines of research could address the best managerial practices for fitness centers' sustainability and continuity from a longitudinal approach. This way, the extent to which the identified elements are affected over time or remain constant could be checked. Additionally, the group of key informants could be increased with participants from diverse nationalities or with other target groups, such as employees or customers.

Author Contributions: Conceptualization, J.L.-Q., J.G.-U., and P.B.; Data curation, J.L.-Q.; Formal analysis, J.L.-Q., J.G.-U., and P.B.; Investigation, J.L.-Q.; Methodology, J.L.-Q., J.G.-U., and P.B.; Resources, J.L.-Q., J.G.-U., and P.B.; Supervision, J.G.-U. and P.B.; Visualization, J.L.-Q., J.G.-U., and P.B.; Writing-original draft, J.L.-Q.; Writing-review and editing, J.L.-Q., J.G.-U., and P.B. All authors have read and agreed to the published version of the manuscript.

Funding: This research received no external funding.

Acknowledgments: The present study was supported by the Faculty of Sport Sciences of Universidad Europea de Madrid. J.G.-U. acknowledges "Fondo Europeo de Desarrollo Regional, Programa Operativo de la Región de Castilla-La Mancha" (2018/11744) for funding the development of his research.

Conflicts of Interest: The authors declare no conflict of interest.

\section{References}

1. International Health, Racquet and Sportsclub Association. The 2019 IHRSA Global Report; IHRSA: Boston, MA, USA, 2019.

2. Europe Active. European Health Fitness Market Report 2020; Europe Active: Brussels, Belgium, 2020.

3. Cheung, R.; Woo, M. Determinants of Perceived Service Quality: An Empirical Investigation of Fitness and Recreational Facilities. Contemp. Manag. Res. 2016, 12, 363-370. [CrossRef]

4. Clavel, I.; García-Unanue, J.; Iglesias-Soler, E.; Felipe, J.L.; Gallardo, L. Prediction of abandonment in Spanish fitness centres. Eur. J. Sport Sci. 2018, 19, 217-224. [CrossRef]

5. Baena-Arroyo, M.J.; García-Fernández, J.; Gálvez-Ruiz, P.; Grimaldi-Puyana, M. Analyzing Consumer Loyalty through Service Experience and Service Convenience: Differences between Instructor Fitness Classes and Virtual Fitness Classes. Sustainability 2020, 12, 828. [CrossRef]

6. García-Fernández, J.; Gálvez-Ruíz, P.; Fernández-Gavira, J.; Vélez-Colón, L.; Pitts, B.; Bernal-García, A. The effects of service convenience and perceived quality on perceived value, satisfaction and loyalty in low-cost fitness centers. Sport Manag. Rev. 2018, 21, 250-262. [CrossRef]

7. Kohl, H.W.; Craig, C.L.; Lambert, E.V.; Inoue, S.; Alkandari, J.R.; Leetongin, G.; Kahlmeier, S.; Andersen, L.B.; Bauman, A.E.; Blair, S.N.; et al. The pandemic of physical inactivity: Global action for public health. Lancet 2012, 380, 294-305. [CrossRef]

8. European Commission Special Eurobarometer 472 Report-Sport and Physical Activity. Available online: https://op.europa.eu/en/publication-detail/-/publication/9a69f642-fcf6-11e8-a96d-01aa75ed71a1 (accessed on 19 May 2020).

9. Thompson, W.R. Worldwide Survey of Fitness Trends for 2020. ACSMs Health Fit. J. 2019, 23, 10-18. [CrossRef] 
10. Batrakoulis, A. European Survey of Fitness Trends for 2020. ACSMs Health Fit. J. 2019, 23, 28-35. [CrossRef]

11. Boulding, W.; Kalra, A.; Staelin, R.; Zeithaml, V.A. A Dynamic Process Model of Service Quality: From Expectations to Behavioral Intentions. J. Mark. Res. 1993, 30, 7-27. [CrossRef]

12. O'Neil, M.A.; Palmer, A. Importance-performance analysis: A useful tool for directing continuous quality improvement in higher education. Qual. Assur. Educ. 2004, 12, 39-52. [CrossRef]

13. Tsitskari, E.; Tzetzis, G.; Konsoulas, D. Perceived Service Quality and Loyalty of Fitness Centers' Customers: Segmenting Members Through Their Exercise Motives. Serv. Mark. Q. 2017, 38, 253-268. [CrossRef]

14. Voráček, J.; Čáslavová, E.; Šíma, J. Segmentation in sport services: A typology of fitness customers. Acta Univ. Carol. Kinanthropol. 2016, 51, 32-47. [CrossRef]

15. León-Quismondo, J.; García-Unanue, J.; Burillo, P. Service Perceptions in Fitness Centers: IPA Approach by Gender and Age. Int. J. Environ. Res. Public Health 2020, 17, 2844. [CrossRef]

16. Burillo, P.; Sánchez-Fernández, P.; Dorado, A.; Gallardo, L. Global customer satisfaction and its components in local sports services. A discrimminat analysis. J. Sports Econ. Manag. 2012, 2, 16-33.

17. Theodorakis, N.; Alexandris, K.; Rodriguez, P.; Sarmento, P.J. Measuring customer satisfaction in the context of health clubs in Portugal. Int. Sports J. 2004, 8, 44-53.

18. Tsitskari, E.; Quick, S.; Tsakiraki, A. Measuring Exercise Involvement Among Fitness Centers' Members: Is It Related With Their Satisfaction? Serv. Mark. Q. 2014, 35, 372-389. [CrossRef]

19. Alexandris, K.; Zahariadis, P.; Tsorbatzoudis, C.; Grouios, G. An empirical investigation of the relationships among service quality, customer satisfaction and psychological commitment in a health club context. Eur. Sport Manag. Q. 2004, 4, 36-52. [CrossRef]

20. Lagrosen, S.; Lagrosen, Y. Exploring service quality in the health and fitness industry. Manag. Serv. Qual. 2007, 17, 41-53. [CrossRef]

21. Polyakova, O.; Mirza, M.T. Service quality models in the context of the fitness industry. Sport Bus. Manag. Int. J. 2016, 6, 360-382. [CrossRef]

22. Calabuig, F.; Quintanilla, I.; Mundina, J. La calidad percibida de los servicios deportivos: Diferencias según instalación, género, edad y tipo de usuario en servicios náuticos. RYCIDE Rev. Int. Cienc. Deporte 2008, 4, 25-43. [CrossRef]

23. Yildiz, S.M. An importance-performance analysis of fitness center service quality: Empirical results from fitness centers in Turkey. Afr. J. Bus. Manag. 2011, 5, 7031-7041.

24. Castillo-Rodriguez, A.; Onetti-Onetti, W.; Chinchilla-Minguet, J.L. Perceived Quality in Sports Centers in Southern Spain: A Case Study. Sustainability 2019, 11, 3983. [CrossRef]

25. Avourdiadou, S.; Theodorakis, N.D. The development of loyalty among novice and experienced customers of sport and fitness centres. Sport Manag. Rev. 2014, 17, 419-431. [CrossRef]

26. Bloemer, J.; De Ruyter, K. Customer loyalty in high and low involvement service settings: The moderating impact of positive emotions. J. Mark. Manag. 1999, 15, 315-330. [CrossRef]

27. Sperandei, S.; Vieira, M.C.; Reis, A.C. Adherence to physical activity in an unsupervised setting: Explanatory variables for high attrition rates among fitness center members. J. Sci. Med. Sport 2016, 19, 916-920. [CrossRef]

28. Clavel, I.; García-Unanue, J.; Iglesias-Soler, E.; Gallardo, L.; Felipe, J.L. Drop out prediction in sport centres. Definition of models and reproducibility. Retos 2020, 37, 54-61.

29. Zeithaml, V.A.; Berry, L.L.; Parasuraman, A. The Behavioral Consequences of Service Quality. J. Mark. 1996, 60, 31-46. [CrossRef]

30. Açak, M. An examination of the decision-making styles of hearing-impaired sports club managers in Turkey. Afr. J. Bus. Manag. 2012, 6, 8309-8319.

31. Çiftçi, S.; Gökçel, B.; Demirkıran, Y. Analyse of the Expectations of the Sports Management Students in Terms of Quality. Procedia Soc. Behav. Sci. 2015, 174, 2602-2609. [CrossRef]

32. Barranco, D.; Grimaldi-Puyana, M.; Crovetto, M.; Barbado, C.; Boned, C.; Felipe, J.L. Differences in Conditions of Employment Between Sport Managers With and Without a Degree in Physical Activity and Sport Sciences. J. Sport Health Res. 2015, 7, 81-90.

33. Ko, L.M.; Henry, I.; Chin Hsun, J. The perceived importance of sport management competencies by academics and practitioners in the cultural/industrial context of Taiwan. Manag. Leis. 2011, 16, 302-317. [CrossRef]

34. Retar, I.; Plevnik, M.; Kolar, E. Key competences of Slovenian sport managers. Ann. Kinesiol. 2013, 4, 81-94.

35. Koustelios, A. Identifying important management competencies in fitness centres in Greece. Manag. Leis. 2003, 8, 145-153. [CrossRef] 
36. Chelladurai, P. Sport Management: Macro Perspectives; Sports Dynamics: London, UK, 1985.

37. Dowling, M.; Edwards, J.; Washington, M. Understanding the concept of professionalisation in sport management research. Sport Manag. Rev. 2014, 17, 520-529. [CrossRef]

38. Boned, C.J.; Felipe, J.L.; Barranco, D.; Grimaldi-Puyana, M.; Crovetto, M. Perfil profesional de los trabajadores de los centros de fitness en España. Rev. Int. Med. Cienc. Act. Física Deporte 2015, 15, 195-210.

39. Mischler, S.; Bauger, P.; Pichot, L.; Wipf, E. Private fitness centres in France: From organisational and market characteristics to micromentalities of the managers. Int. J. Sport Manag. Mark. 2009, 5, 426-449. [CrossRef]

40. García-Fernández, J.; Bernal-García, A.; Fernández-Gavira, J.; Vélez-Colón, L. Analysis of existing literature on management and marketing of the fitness centre industry. S. Afr. J. Res. Sport Phys. Educ. Recreat. 2014, 36, 75-91.

41. Cunningham, G.B. Theory and theory development in sport management. Sport Manag. Rev. 2013, 16, 1-4. [CrossRef]

42. Zaharia, N.; Kaburakis, A. Bridging the Gap: U.S. Sport Managers on Barriers to Industry-Academia Research Collaboration. J. Sport Manag. 2016, 30, 248-264. [CrossRef]

43. Varmus, M.; Kubina, M.; Koman, G.; Ferenc, P. Ensuring the Long-Term Sustainability Cooperation with Stakeholders of Sports Organizations in SLOVAKIA. Sustainability 2018, 10, 1833. [CrossRef]

44. Freitas, A.L.P.; Lacerda, T.S. Fitness centers: What are the most important attributes in this sector? Int. J. Qual. Res. 2019, 13, 177-192. [CrossRef]

45. Vieira, E.; Ferreira, J.J. Strategic framework of fitness clubs based on quality dimensions: The blue ocean strategy approach. Total Qual. Manag. Bus. Excell. 2017, 29, 1648-1667. [CrossRef]

46. Miles, M.B.; Huberman, A.M. Qualitative Data Analysis: An Expanded Sourcebook, 2nd ed.; SAGE Publications: Thousand Oaks, CA, USA, 1994.

47. Felipe, J.L.; Gallardo, L.; Burillo, P.; Gallardo, A.; Sánchez-Sánchez, J.; Plaza-Carmona, M. A qualitative vision of artificial turf football fields: Elite players and coaches. S. Afr. J. Res. Sport Phys. Educ. Recreat. 2013, 35, 105-120.

48. Rodríguez-Cañamero, S.; Gallardo, L.; Ubago-Guisado, E.; García-Unanue, J.; Felipe, J.L. Causes of customer dropouts in fitness and wellness centres: A qualitative analysis. S. Afr. J. Res. Sport Phys. Educ. Recreat. 2018, 40, 111-124.

49. Morse, J. The Significance of Saturation. Qualitative Health Research. Qual. Health Res. 1995, 5, 147-149. [CrossRef]

50. Alcaraz, N.; Soriano, C.; López, A.; Rosa, D.; Magraner, L.; Porcar, R.M.; Such, M.J.; Sánchez, J.J.; Prat, J.M. Factores de Éxito Desde la Perspectiva del Usuario en Instalaciones Deportivas, de ocio y Salud en Comunidad Valenciana; Instituto de Biomecánica de Valencia: Valencia, Spain, 2009.

51. Elasri, A.; Triadó, X.M.; Aparicio, P. La satisfacción de los clientes de los centros deportivos municipales de Barcelona. Apunt. Educ. Física Deporte 2015, 119, 109-117. [CrossRef]

52. Nuviala, A.; Grao-Cruces, A.; Tamayo, J.A.; Nuviala, R.; Álvarez, J.; Fernández-Martínez, A. Diseño y análisis del cuestionario de valoración de servicios deportivos (EPOD2). Rev. Int. Med. Cienc. Act. Física Deporte 2013, 13, 419-436.

53. Rial, A.; Rial, J.; Varela, J.; Real, E. An application of importance-performance analysis (IPA) to the management of sport centres. Manag. Leis. 2008, 13, 179-188. [CrossRef]

54. Sánchez, J. Business \& Fitness. El Negocio de los Centros Deportivos; Editorial UOC: Barcelona, Spain, 2011.

55. Glaser, B.G.; Strauss, A. The Discovery of Grounded Theory: Strategies for Qualitative Research; Aldine: Chicago, IL, USA, 1967.

56. Corbin, J.; Strauss, A. Basics of Qualitative Research: Techniques and Procedures for Developing Grounded Theory, 4th ed.; SAGE Publications: Thousand Oaks, CA, USA, 2014.

57. Dhurup, M.; Singh, P.C.; Surujlal, J. Customer service quality at commercial health and fitness centres. S. Afr. J. Res. Sport Phys. Educ. Recreat. 2006, 28, 39-54. [CrossRef]

58. Faulkner, G.; Dale, L.P.; Lau, E. Examining the use of loyalty point incentives to encourage health and fitness centre participation. Prev. Med. Rep. 2019, 14, 100831. [CrossRef]

59. Afthinos, Y.; Theodorakis, N.D.; Nassis, P. Customers' expectations of service in Greek fitness centers. Gender, age, type of sport center, and motivation differences. Manag. Serv. Qual. 2005, 15, 245-258. [CrossRef]

60. García-Fernández, J.; Fernández-Gavira, J.; Durán-Muñoz, J.; Vélez-Colón, L. La actividad en las redes sociales: Un estudio de caso en la industria del fitness. Retos 2015, 28, 44-49. 
61. Williams, J.; Chinn, S.J. Meeting Relationship-Marketing Goals Through Social Media: A Conceptual Model for Sport Marketers. Int. J. Sport Commun. 2010, 3, 422-437. [CrossRef]

62. Chao, R.F. The Impact of Experimental Marketing on Customer Loyalty for Fitness Clubs: Using Brand Image and Satisfaction as the Mediating Variables. J. Int. Manag. Stud. 2015, 10, 52-60.

63. Mañas-Rodríguez, M.Á.; Giménez-Guerrero, G.; Muyor-Rodríguez, J.M.; Martínez-Tur, V.; Moliner-Cantos, C.P. Los tangibles como predictores de la satisfacción del usuario en servicios deportivos. Psicothema 2008, 20, 243-248. [PubMed]

64. Liu, Y.D.; Taylor, P.; Shibli, S. Measuring customer service quality of English public sport facilities. Int. J. Sport Manag. Mark. 2009, 6, 229-252. [CrossRef]

65. Vieira, E.; Ferreira, J.J.; São João, R. Creation of value for business from the importance-performance analysis: The case of health clubs. Meas. Bus. Excell. 2019, 23, 199-215. [CrossRef]

66. Arias-Ramos, M.; Serrano-Gómez, V.; García-García, O. ¿Existen diferencias en la calidad percibida y satisfacción del usuario que asiste a un centro deportivo de titularidad privada o pública? Un estudio piloto. Cuad. Psicol. Deporte 2016, 16, 99-110.

67. Rodríguez-Cañamero, S.; García-Unanue, J.; Felipe, J.L.; Sánchez-Sánchez, J.; Gallardo, L. Why do clients enrol and continue at sports centres? Sport Bus. Manag. Int. J. 2019, 9, 273-283. [CrossRef]

68. Lee, Y.L.; Pan, L.Y.; Hsu, C.H.; Lee, D.C. Exploring the Sustainability Correlation of Value Co-Creation and Customer Loyalty-A Case Study of Fitness Clubs. Sustainability 2018, 11, 97. [CrossRef]

(C) 2020 by the authors. Licensee MDPI, Basel, Switzerland. This article is an open access article distributed under the terms and conditions of the Creative Commons Attribution (CC BY) license (http://creativecommons.org/licenses/by/4.0/). 